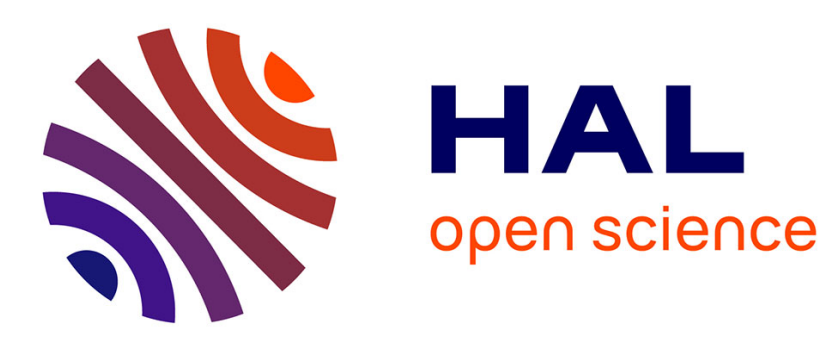

\title{
Co-optation, Cooperation or Competition? Microfinance and the new left in Bolivia, Ecuador and Nicaragua
}

Florent Bédécarrats, Johan Bastiaensen, François Doligez

\section{To cite this version:}

Florent Bédécarrats, Johan Bastiaensen, François Doligez. Co-optation, Cooperation or Competition? Microfinance and the new left in Bolivia, Ecuador and Nicaragua. Third World Quarterly, 2012, 33 (1), pp.143 - 160. 10.1080/01436597.2012.627245 . hal-01722449

\section{HAL Id: hal-01722449 \\ https://hal.science/hal-01722449}

Submitted on 4 Mar 2018

HAL is a multi-disciplinary open access archive for the deposit and dissemination of scientific research documents, whether they are published or not. The documents may come from teaching and research institutions in France or abroad, or from public or private research centers.
L'archive ouverte pluridisciplinaire HAL, est destinée au dépôt et à la diffusion de documents scientifiques de niveau recherche, publiés ou non, émanant des établissements d'enseignement et de recherche français ou étrangers, des laboratoires publics ou privés. 


\title{
Co-optation, Cooperation or Competition? Microfinance and the New Left in Bolivia, Ecuador and Nicaragua Florent Bédécarrats, Johan Bastiaensen, François Doligez
}

\begin{abstract}
The last decade has been marked by the resurgence of leftist political movements across Latin America. The rise of the 'New Left' masks the ambivalent relationships these movements have with broader society, and their struggle to find an alternative to the prevailing development model. Across the continent, the microfinance sector, filling the void left by failed public banks, has grown significantly under an increasingly commercial form. Analysis of Nicaragua, Ecuador and Bolivia reveals that the new governments share a common distrust of microfinance. Yet, in the absence of viable alternatives for financial service provision, governments and microfinance stakeholders are forced to coexist. The environment in which they do so varies greatly, depending on local political and institutional factors. Some common trends can nevertheless be discerned. Paradoxically, the sector seems to be polarized into two competing approaches which reinforce the most commercially-oriented institutions on the one hand, and the most subsidized ones on the other, gradually eliminating the economically viable microfinance institutions which have tried to strike a balance between social objectives and the market.
\end{abstract}

\section{Introduction $^{1}$}

The role of microfinance in the development process is subject to debate. After receiving worldwide recognition with the UN's International Year of Microcredit in 2005 and the Nobel Peace Prize in 2006 to a Bangladeshi microfinance icon, microfinance is currently being challenged by the new Latin American left -in the very place where the sector's growth has been most impressive. These new leftist governments have adopted differing positions with regard to microfinance actors and the mainstream microfinance paradigm that has reigned for the last two decades.

The phenomenon calls for fresh analysis from a political economy perspective to understand this contested redefinition of microfinance's role in countries where political powers are appealing for a socialist approach. Although microfinance is being questioned everywhere, the climate in Brazil seems to be one of acceptance and complementarity ${ }^{2}$, unlike the confrontational atmosphere observed in Nicaragua ${ }^{3}$. The situation is more ambiguous in Bolivia $^{4}$, Ecuador ${ }^{5}$, and El Salvador.

Are we witnessing in Latin America the reintroduction of state intervention in a sector that has matured under a private commercial model? After the 'lost decade' of development, are we moving towards a new relationship between the political elite and citizens, one that offers more protection to the vulnerable in exchange for increased dependence on their leaders? Should we qualify as populist these governments' attempts to take control of microfinance institutions (MFIs), which, under the pretext of expanded financial access and lower interest rates, ultimately threaten the sector's sustainability and subject it to clientelistic manoeuvrings? Are we seeing the emergence of a new institutionalised forum that reconciles regulation, public policies and private initiative, or simply superficial attempts to manage tensions, which are destined to fail?

The prevailing discourse rarely goes beyond conflicting orthodoxies claiming either state or market superiority. Indeed, it is only very recently that a few microfinance actors have begun 
to reconsider possible linkages to public programmes, especially in the agriculture and rural sectors $^{6}$. In this article, we compare the relationship between the microfinance sector and leftist governments in three Latin American countries. After examining the historical trends underpinning these recent political shifts, we will summarize the confrontations between public policy and microfinance in Bolivia, Nicaragua and Ecuador. We then propose an analytical framework to categorize the dynamics at work in each of these countries, and the strategies microfinance actors are using to reposition themselves in this new environment.

\section{The heated debate over development finance}

\section{The Latin American left: a mixed political reality}

After several decades of repressive dictatorship and increasingly contested neoliberal governments, left-wing coalitions returned to power in Venezuela (1999), Brazil (2002), Argentina (2003), Uruguay (2005), Honduras, Chile, Bolivia (2006), Ecuador, Nicaragua (2007), Paraguay (2008), El Salvador (2009) and Peru (2011). The spectacular rise of this new left in the form of social movements, political parties and governments cannot be ignored by financial and development institutions ${ }^{7}$. Indeed, despite their heterogeneity, these new leftist actors all claim to represent an ideological and symbolic rupture from neoliberalism and wilfully challenge assumptions of state inefficiency and the predominance of private initiative and markets as the most effective modes of organizing society and the economy ${ }^{8}$.

Some researchers analyse this political dynamic in binary terms that oppose a populist, statecentred and authoritarian left with a social democratic one that is more modern and reformist ${ }^{9}$. Although this typology is useful for distinguishing the extremes of the leftist political spectrum, it induces a simplistic perspective that impedes understanding of the forces at play between the grass-roots and heads of partisan organizations, and the processes that lead to policy formulation ${ }^{10}$. To grasp the multiple dimensions in which these interactions unfold, it is important to take into account the cognitive and normative elements that drive the discourses, paradigms and conceptual frameworks of the new lefts, as well as their interests and institutions - defined as the ensemble of rules and practices that affect behaviour and mark historical inertia ${ }^{11}$. Therefore it is useful to examine the segments of society involved in mobilizing voters and activists, but also the diverse backgrounds of the political elites.

Leftist governments in Latin America claim to be so strongly opposed to previous policies that many have undertaken deep constitutional reforms to make a clean break. However, whether they can translate these changes into an alternative development model is questionable. So far, governments have promoted more egalitarian income distribution, but have remained attentive to macroeconomic equilibrium. In most cases, changes have materialized through expanded social welfare programmes to benefit the poorest. Although these redistribution mechanisms create enormous opportunities in terms of health and education, they are based on existing modes of production, in particular tax revenues from the primary sector, and are not paired with more structural economic reforms ${ }^{12}$. Recent political shifts have done little more than reinforce the 'trickle down' orthodoxy without questioning the requirements of expanded reproduction of private capital and the new 'post-Washington consensus ${ }^{13}$.

We must be careful not to idealize the relationship between governments, parties and social movements. There is much to be learned from the manoeuvrings and reversals of alliances between the constituents of these organizations and the 'professional politicians' that emerge from them ${ }^{14}$. The left's accession to power in several countries coincides with a polarization of politics and rising tensions between those in power and the opposition. These tensions tend to reinforce clientelistic strategies and push the new governments to mobilize all available 
resources to strengthen their popular support. The pervasiveness of such power struggles is further exacerbated when the executive branch assumes control of administrative or judicial authorities.

\section{Poverty champions or loan sharks?}

The economic history of Latin America is particularly scarred by the collapse of state banks and government credit programmes. The main tools of development finance in 1960s and 1970s, state-run banks and programmes were notorious for being highly dysfunctional: cumbersome loan procedures, poor internal control, unqualified and occasionally corrupt staff and clientelistic management practices ${ }^{15}$. These failings, absorbed by public finances, played a major role in the 'debt crisis' of many developing countries ${ }^{16}$. The idea that such defects are intrinsic to public finance mechanisms took root in the minds of researchers, policy makers and development professionals ${ }^{17}$, and eradicating public intervention became a priority of the structural adjustment policies imposed by international financial institutions, lenders of last resort to bankrupt states.

After these reforms, whole sections of the economy were left without access to credit and savings, despite being essential to their functioning and growth ${ }^{18}$. Community organizations and Non-Governmental Organizations (NGOs) attempted to remedy this financial exclusion through initiatives often promoted by former managers of public credit programmes and deteriorating cooperatives, or by international faith-based organizations. Despite their diversity, these organizations converged in their opposition to state intervention in development finance ${ }^{19}$ and helped structure the foundations of a private microfinance sector in line with the monetary and fiscal policies of their governments. MFIs hence developed as an alternative form of finance, well suited to the growing informal sector, and became a preferred solution to poverty and underemployment, ideologically compatible with neoliberalism ${ }^{20}$.

In order to reduce subsidy dependency and attract private investors, international donors supporting the sector emphasized financial sustainability, pushing MFIs to cover their costs, commercialize operations and turn a profit, in order to ultimately integrate the international financial system ${ }^{21}$. As a result, microfinance NGOs increasingly sought to transform into commercial entities; credit and savings cooperatives, on the other hand, struggled to adapt to this new paradigm and continued to be marginalized. Although microfinance usually mobilizes insignificant volumes in macroeconomic terms, it affects an enormous number of people. In 2008, Latin American MFIs managed nearly 13 million loans totalling more than $\$ 13.9$ billion and 13.4 million savings accounts for a volume of $\$ 9$ billion ${ }^{22}$. The table below gives key indicators for Bolivia, Nicaragua and Ecuador. 
Manuscript accepted for publication, uploaded to HAL in accordance with the French loi pour une République Numérique.

Key data on microfinance in Bolivia, Nicaragua and Ecuador

\begin{tabular}{|c|c|c|c|}
\hline & Bolivia & Nicaragua & Ecuador \\
\hline \multicolumn{4}{|c|}{ Financial inclusion (December 2009) } \\
\hline Total number of active lenders (i) & 1.122 .507 & 686.701 & 1.968 .856 \\
\hline Active lenders as $\%$ of the total population & $19 \%$ & $20 \%$ & $23 \%$ \\
\hline Active microfinance lenders & 865.464 & 391.375 & 656.986 \\
\hline Active microfinance lenders as $\%$ of total population & $15 \%$ & $11 \%$ & $8 \%$ \\
\hline \multicolumn{4}{|c|}{ Dimension and evolution of the sector (December 2009) } \\
\hline Amount of credit outside of microfinance (million USD) (ii) & 4.038 & 1.278 & 10.701 \\
\hline Amount of microfinance credit (million USD) & 1.854 & 472 & 1.281 \\
\hline Share of microfinance in the national financial sector & $31,5 \%$ & $27,0 \%$ & $10,7 \%$ \\
\hline Three main microfinance institutions of the country & $\begin{array}{c}\text { ProCredit, } \\
\text { BancoSol, } \\
\text { FIE }\end{array}$ & $\begin{array}{l}\text { Banex, } \\
\text { ProCredit, } \\
\text { FDL }\end{array}$ & \begin{tabular}{|c} 
CrediFé, Banco \\
Solidario, \\
ProCredit
\end{tabular} \\
\hline Number of lenders of the three main MFIs & 356.279 & 148.219 & 263.132 \\
\hline $\begin{array}{l}\text { Share of the three main MFIs in the microfinance sector } \\
\text { (\#lenders) }\end{array}$ & $41 \%$ & $38 \%$ & $40 \%$ \\
\hline Portfolio of the three main MFIs (million USD) & 1.038 & 299 & 693 \\
\hline $\begin{array}{l}\text { Share of the three main MFIs in the microfinance sector } \\
\text { (\#loan volume) }\end{array}$ & $56 \%$ & $63 \%$ & $54 \%$ \\
\hline $\begin{array}{l}\text { Annual portfolio growth of the microfinance sector (2006 - } \\
\text { 2009) }\end{array}$ & $28 \%$ & $7 \%$ & $15 \%$ \\
\hline $\begin{array}{l}\text { Annual portfolio growth of the three main MFIs (2006 - } \\
\text { 2009) }\end{array}$ & $32 \%$ & $10 \%$ & $12 \%$ \\
\hline \multicolumn{4}{|c|}{ Interest rates and rates of return (2008) } \\
\hline Average portfolio yield of the microfinance sector & $23,22 \%$ & $31,76 \%$ & $22,47 \%$ \\
\hline Average portfolio yield of the three main IMFs & $19,64 \%$ & $26,55 \%$ & $17,68 \%$ \\
\hline Average return on equity of the microfinance sector & $9,06 \%$ & $6,05 \%$ & $5,65 \%$ \\
\hline Average return on equity of the three main MFIs & $12,99 \%$ & $15,36 \%$ & $19,04 \%$ \\
\hline \multicolumn{4}{|c|}{$\begin{array}{l}\text { Sources: Data obtained from the Microfinance Information eXchange (www.mix.org), except for } \\
\text { (i): Data for Bolivia were obtained from ASOFIN (www.asofin-bo.org). Since there were no data available for } \\
\text { Ecuador and Nicaragua, the values were extrapolated from data collected by the World Bank in 2004, assuming } \\
\text { that average loan amounts remained stable. (They are thus very tentative estimates.) } \\
\text { (ii): Data calculated from the statistics of the National Banking Oversight Institutions, deducing the amounts of the } \\
\text { regulated microfinance institutions. }\end{array}$} \\
\hline
\end{tabular}

As these figures show, MFIs already play a significant role in the national economies of the countries in question and are growing rapidly. This expansion has not come without criticism. Due to the constraints of an often costly retail business striving to be sustainable ${ }^{23}$, microfinance interest rates are significantly higher than traditional bank loans, as evidenced by the average portfolio yields above ${ }^{24}$. This paradox elicits heated debate as to their fairness and the poor's capacity to support such costs, especially when they lead to significant gains for MFIs ${ }^{25}$. Microfinance's supporters point out the prohibitive cost of the alternatives available to the poor, such as moneylenders. Arguing that the main constraint is supply, they caution against interest rate caps and recommend letting competition and economies of scale drive rates down. However, the latter does not appear to occur automatically, as increased efficiency only partially translates into lower interest rates; rather, it appears to fuel particularly high levels of profitability, as is the case of the largest institutions in Ecuador, Bolivia and Nicaragua (see table). While many population segments, especially in rural areas, still lack access to microfinance, the excessive urban concentration of institutions has resulted in regional and nationwide debt crises, sometimes exacerbated by the development of consumer credit ${ }^{26}$. In some countries, urban market saturation has led to rapid expansion into so-called easy segments of the rural market, resulting in lax and even reckless lending 
practices, dramatically deteriorating portfolio quality. Private credit bureaus, presented as tools to curb multiple loans, have cropped up in almost all Latin American countries, allowing financial institutions to share information about customers. However, governments rarely consult these agencies, which are not obligatory and moreover do not include the informal finance mechanisms that continue to play a fundamental role in the dynamics of debt ${ }^{27}$ but manage to stay outside the purview of government regulation.

\section{National trajectories}

\section{The uncertain future of microfinance in Bolivia}

Bolivia, a pioneer in microfinance, has become the flagship for commercial microfinance. MFIs' portfolios represent 31.5 per cent of the country's financial system in volume and the sector serves the majority (70 per cent) of customers ${ }^{28}$. After an intense growth phase in the 1990s, during which nearly a million (primarily urban) clients were served, the country was rocked by its first debt crisis and confrontations with 'debtors' associations' between 1999 and 2002. It pushed the nascent 'microfinance industry' to develop mechanisms to better manage competition, such as credit bureaus and codes of conduct for institutions. The episode spared, even reinforced, two non-profit organizations: CRECER and PROMUJER, both oriented towards women and reputed as having the most socially oriented practices in the sector ${ }^{29}$.

Movement for Socialism (MAS) leader Evo Morales completed his first presidential term between 2006 and 2009. It was marked by several major reforms, including changes to the constitution and the nationalization of hydrocarbon industries, but also a polarization of politics, crystallized by the antagonism between the executive branch on the one hand and the legislative and judicial branches on the other, as well as confrontations between indigenous Altiplano populations and those from eastern parts of the country ${ }^{30}$. With its landslide victory in December 2009, MAS now controls most of the political institutions, which has eliminated the obstacles of his previous term. Popular expectations are very high. Evo Morales' party appears to be structured around two components: one, of Marxist origins, has long played a role in the political system and has close ties to the microfinance elite. The other, associated with indigenous groups and popular movements, is often at odds with the first.

This somewhat disparate left takes an ambiguous stance with regard to microfinance. While it depicts MFIs as usury lenders during elections, with MAS candidates promising loans at single digit interest rates, the party has made only patchy attempts at real action. The Bolivian regulatory framework was a paragon for commercial microfinance ${ }^{31}$ because it prioritized profitability and stability, thus encouraging the standardization of practices to the detriment of development objectives ${ }^{32}$. There was a shift in 2006, when Evo Morales named a former public sector banker active in microfinance as Commissioner of the highly orthodox Banking Commission, and then again in 2008 when the latter called for the Central Bank to supervise NGOs, thus far unregulated. Despite a protracted accreditation process, NGOs will soon have the possibility to mobilize savings. But this window of opportunity to build a non-profit, rural and socially oriented microfinance sector does not appear to be a government priority. Indeed, shortly after these changes, the Banking Commission was abolished to create a supervisory authority controlled by the Ministry of Economy. The reform affected all administrative authorities independent of the executive branch, and was accompanied by large staff turnover. In substituting financial specialists deemed too technocratic with less experienced political appointees, the supervisory body lost the technical capacity to effectively monitor a sector still vulnerable to bankruptcy and fraud.

Besides regulation, the government has taken measures to increase funding at the local level. With Venezuelan capital, it created the state-controlled Banco de Desarrollo Productivo 
(BDP)to channel cash transfer programmes and refinance microfinance institutions, as well as to directly provide credit to farmers' and artisans' organizations. However, the start-up capital was not renewed and the BDP's activities have remained confined to a small, local loan fund for existing financial institutions, supervised by four ministries competing for its control. . During the late 2009 electoral campaign, MAS party rhetoric stressed the need to create a genuine state-owned development finance mechanism, often mentioned in conjunction with a possible regulation of microfinance interest rates. However, these declarations have yet to give rise to concrete measures.

Even though the government's positions may ultimately change, microfinance institutions feel they are under threat of political take-over. Some non-financial NGOs have already been 'expropriated' by organizations close to the MAS. Among the MFIs, however, only AGROCAPITAL has seen its development restrained and this for very specific reasons. This institution, initiated by USAID, had indeed actively participated in the programmes for the eradication of coca production and was a target mainly on this account. Other MFIs have not been affected, but the situation may evolve. Surely, the new constitution explicitly gives a voice to social movements, making it an obligation to involve them whenever public funds are used, and, by extension, funds from international development agencies. This has reinforced militant groups close to the MAS in relation to the microfinance sector

In light of these threats, some microfinance institutions are fostering ties with private banks, in anticipation of a decree that will force the latter to direct part of their portfolios to microcredit, like in Venezuela. For many MFIs, integrating the banking sector seems like the best protection against political whims. Not only is the latter exempt from obligations to involve social movements, it can apply particularly high interest rates on credit cards without worrying about sanctions. Other MFIs, particularly NGOs affiliated with the national microfinance network, are focusing on policy dialogue. They are striving to demonstrate their social utility by building alliances with farmers' organizations, while emphasizing their complementarity to public policies by offering to mediate the government's cash transfer programmes.

\section{Nicaragua: Chronicle of a Crisis Foretold}

The Development Bank of Nicaragua was liquidated in the early 1990s, during the political transition between the Sandinistas and the Liberal government. A first wave of commercial banks created at the same time quickly went bankrupt, often due to fraud. Microfinance flourished in this context in various forms. Commercial microfinance banks, supervised by the Banking Commission and authorized to collect savings from the public, experienced growth of 42 per cent a year between 2004 and $2008^{33}$, largely supported by public and private investors. Meanwhile, NGOs grew an average of 24 per cent per year, somewhat slower than their commercial counterparts, due to regulatory constraints on savings mobilization and due to the decisions of public donors who, following the recommendations of multilateral institutions ${ }^{34}$, spurned support to unregulated non-profit organisations often concentrated in rural microfinance. Nevertheless, the success of a few rural-focused NGOs, such as Fondo de Desarrollo Local (FDL), Prestanic and Fundeser, generated growing interest among social and even commercial investment funds ${ }^{35}$. There are also some cooperatives, but they are significantly smaller. In late 2008, it was estimated that the key players served more than half a million customers, representing a significant proportion of the roughly one million small businesses in the country ${ }^{36}$. Although this estimate is an approximation, market saturation is evident, with most cases of over-indebtedness in urban areas and among livestock farmers. 
Procredit and Banex, two regulated microfinance banks strongly supported by mainstream champions of profitable microfinance, engaged in a strategy of expansion and aggressive competition. This was made possible and even necessary due to major liquidity injections from public donors and, to a lesser extent, private investors. In doing so, they sought to eliminate unregulated MFIs lacking comparable financial resources. Thanks to their institutional quality and rural outreach, however, many of these MFIs resisted and managed to secure international funding to sustain portfolio growth.

This headlong rush led to relaxed risk control, multiple lending and over-indebtedness, thereby creating the conditions for a genuine debt crisis across the sector, triggered by an acute recession that hit traders hard in 2009. The recession was exacerbated by the depression that gripped livestock farmers, economic pillars of northern Nicaragua, due to declining demand for cattle in Mexico, itself due to soaring maize prices caused by the explosion of subsidized demand for bio-ethanol in the US, as well as the application of new trade regulations prohibiting exports of cattle under $330 \mathrm{~kg}$. This spiral led most MFIs to accumulate bad loans and stiffen their collection practices. Particularly affected by the crisis, Banex liquidated in 2010 while Procredit had to be recapitalized by its international holding. The latter, seeking to move towards a more creditworthy clientele, raised its minimum loan amount to $\$ 2500$.

The Sandinista party returned to power in Nicaragua in 2007 after 18 years of opposition. Its victory was not the result of more votes - it registered the same 38 per cent as it had for over a decade - but the fruit of a divided opposition and political manoeuvrings that allowed the best candidate with more than 35 per cent to take office without a second round of elections. This explains why consolidating popular support became the new government's top priority. It sought to reinforce clientelistic relationships through social programmes, including subsidized microcredit financed with Venezuelan funds, and economic networks created around Venezolano-Nicaraguan private companies, federated under a consortium called ALBA ('dawn' in Spanish), controlled by a nepotistic political network. These relationships were forged through local intermediaries, like cooperatives, that played an important role as subsidy brokers among small-scale economic actors in exchange for their partisan allegiance. To secure support in rural areas, the government pushed for the creation of ALBA-Caruna, which transformed an existing savings and credit cooperative created by a Sandinista peasant organization, and significantly expanded its operations with the proceeds from Venezuelan petroleum deliveries ${ }^{37}$.

It is against this backdrop that a movement driven by entrepreneurs close to the Sandinista party emerged in 2008 in the north. It originally set out to condemn practices used by supervised MFIs, such as the seizure of collateral and imprisonment for fraud, the only institutions allowed this type of legal recourse in the event of default. Following initial negotiations and agreement between local representatives of the movement, known as No Pago, and MFIs, the President Ortega himself encouraged his audience to rebel against these 'loan sharks' during a public speech in Jalapa 13 July 2008:

'I told you that you must protest, you must complain; I understand the complaints because undoing all the chains set up by governments serving the oligarchy and the Empire in just one year and a half is not easy. They have put us in chains from all sides. You did the right thing to protest against the moneylenders, but instead of protesting in the streets, protest outside the offices of these loan sharks and install your picket line in front of their offices. Stand strong, we support you! (...) They are threatening to stop lending, but what they do is not a favour, it is a business, designed to enrich themselves at the expense of the needs of the people since the people's banks disappeared in 1990.,38 
The next day sparked off months of violent clashes between the No Pago groups and MFI staff, inaugurated by setting fire to a microfinance NGO that had nothing to do with the initial reimbursement disputes, but was notorious for being close to members of the liberal opposition.

This political strategy intensified with the over-indebtedness crisis in 2009. The situation was exploited by local elites (often among the biggest defaulters) who were the main instigators and coordinators of the riots and appeared to be manoeuvring to reinforce their clientelistic networks by ensuring groups that debts would be cancelled. The occasionally violent conflict continued throughout 2009, with the government vacillating in its positions towards microfinance, ultimately maintaining an ambiguous policy that reflected local power dynamics. The opposition's claims gradually shifted from repayment issues to interest rates. Under pressure from the No Pago movement and with the support of Sandinista and nonSandinista politicians representing livestock farmers in the north, a bill was introduced 13 April 2010 allowing defaulters to refinance their loans for five years at 18 per cent per annum. Despite all the fervour in the struggle for this Moratorium Law, only a small portion of the No Pago debtors made use of it, apparently counting on more significant debt remissions in the electoral campaign of 2011. The introduction of a new Microfinance bill in June 2011, however, seems to have opened a new era of more cooperative relationships between the government and the microfinance sector, and political support for the No Pago appears to have waned ${ }^{39}$. How these relationships further evolve remains to be seen.

In this context, as in Bolivia, the trend is for mature NGOs to prepare their transformation into commercial structures, in order to be regulated by the Banking Commission and thus extricate themselves from government intervention. However, it is a trend that limits the pursuit of social objectives, particularly in rural development. And yet, faced with political threats, the private sector paradoxically offers better regulatory protection than the non-profit sector.

\section{Ecuador: measures to undermine the sector remain 'manageable'}

The microfinance in Ecuador is composed of large organizations, banks and cooperatives, supervised by the Central Bank, and a range of unregulated NGOs and small cooperatives. In addition, there are two public banks that are unfortunately mismanaged, operate at a loss, are often manipulated for political ends, and rely on frequent injections; they are considered among the most dysfunctional in the region ${ }^{40}$.

The Ecuadorian left united around the Alianza País coalition in 2006 to bring Rafael Correa to power. A former economics professor, Correa had a fleeting experience as finance minister before he was sacked under pressure from international financial institutions, which opposed his measures. Shortly after taking office in January 2007, he dismissed the World Bank's representative and launched a process of constitutional reforms, creating the foundation, in 2008, for major shifts in economic policy: greater control of oil resources and emphasis on a solidarity-based economy. Correa surrounded himself with an elite that was not representative of the traditional ruling parties: ministers came from NGOs, consulting firms and, to a lesser extent, academia ${ }^{41}$.

Drawing on his academic experience as a professor, the president has developed an economic plan structured around three areas: public, private-entrepreneurial and popular. The latter corresponds to microenterprises. Under this plan, the solidarity-based economy is at the confluence of these three areas and includes both participatory governance, social services, civil society and social economy enterprises ${ }^{42}$. Different from the 'progressive' neoliberal vision that sought to include individual entrepreneurs in the mainstream market, Correa's 
approach, endorsed by the new constitution, enables their growth in an economic sphere that is a hybrid between capitalism, mutualism and the State.

A new bill, enacted May 11, 2011, seeks to prioritize the concept of 'popular finance', based on a criterion of collective ownership, over that of microfinance, defined by the type of products offered and the poverty level of its users. This law, which does not recognize the status of microfinance NGOs, would force them to either become for-profit entities or turn into cooperatives. Up to now, the law remains rather vague about the practical implications of its principles and several crucial modalities will have to be defined in the regulations expected by the end of 2011. Moreover, the government has challenged the allocation of international development aid and created an institute to coordinate donor initiatives so that their efforts converge with priorities established under national development planning. For now, the new priorities are not restrictive, but the government's efforts to collect information and assign each NGO to a ministry suggests its intention to include the non-governmental sector in its institutional framework.

The government has made changes to the institutional environment in which microfinance operates. Since his inauguration, Correa has repeatedly threatened the 'golden bureaucrats' and criticised the independence of some institutions vis-à-vis the elected representatives of the people. Thus, in addition to cross-cutting measures to reduce civil servants pay scales, the Central Bank has been monitored more closely. Technocrats have been replaced by political appointees with less technical capacity and expertise. The President has also opposed multilateral institutions, often more symbolically than operationally, such as in publicized stances against World Bank and IMF in 2007 and 2008, and through the support for the ALBA-related Banco del Sur, which still only exists on paper.

The government has also established a $\$ 40$ million fund, administered by the Ministry of Social Development, for MFI on-lending. In order to ensure the social utility of institutions being refinanced, the government has developed a tool to assess social performance based on a widely recognized international social audit tool ${ }^{43}$. It also has a direct credit programme called ' $5,5,5$ ', which lends $\$ 5000$ for 5 years at 5 per cent per annum. Many observers believe the programme was designed for political purposes and denounce poor management. Some mischievously add the number ' 40 ' to the name, referring to the program's default rate.

In this context, Red Financiera Rural, the national microfinance network that federates most of the MFIs in the country, has emerged as an ineluctable mediating body. It has organized training sessions on microfinance for new hires at the Central Bank, and more importantly, in light of the government's scathing reports and declarations concerning interest rate caps, has led intense negotiations with the government to ensure caps are applied incrementally. The majority of MFIs have managed to formally comply. Even the unofficial spokeswoman of commercial microfinance has admitted that 'the policy at least has the virtue of providing clear signals and allowing time to adjust ${ }^{, 44}$.

\section{A complex, ambivalent relationship}

\section{Conflicts imbued with ideological antagonism}

In each of the cases presented above, the brutal disagreement that has occurred in the aftermath of political shifts can be traced to a challenging of the status quo on subsidiarity between the state and private initiative. Neo-liberal reforms gave the impression that the state was withdrawing from its sovereign functions ${ }^{45}$ to allow the market to organize profitable activities and delegate the management of vulnerable populations to private solidarity-based organizations or international development aid. Today, microfinance and socialist movements 
have something in common: their raison d'être and mission is to improve the living conditions of the poor and excluded. Yet they belong to different registers. The first insists on its technical expertise and apolitical nature, while the latter considers itself a vector allowing groups that suffer from a lack of political representation to exist in the public arena.

Despite this shared purpose and potential complementarity, attempts to articulate the two inevitably run up against profound differences stemming from the two movements' genealogy. Microfinance has for the most part thrived in the wake of structural adjustment, filling a void created by dismantled of social systems and the withdrawal of state intervention in the economy. Moreover, MFIs have often received the support of the same international institutions that imposed financial deregulation, fiscal austerity and trade liberalization - the very measures that today's social movements are fighting against. The socialist movements diametrically oppose multilateral organizations and criticize all the measures the latter have supported. Microfinance's alleged ties to these organizations make them the target of historical revenge, usually presented as a consequence the left's destruction of the 'projectorate' ${ }^{46}$ imposed by international development agencies.

Leftist movements reproach microfinance for a variety of reasons, which together constitute a structured argument ${ }^{47}$. At the centre is the debate on interest rates, described as exorbitant by movements whose social ethos does not sit well with poor people paying more than the rich. Microfinance providers are also criticized for their intransigent collection practices when it comes to dealing with recovering loans from poor clients prone to repayment difficulties. Such firmness contradicts the discourse of the left, which highlights collective rather than individual responsibility when it comes to inequality ${ }^{48}$ and considers the poor as citizens and loyal supporters rather than as entrepreneurs who require discipline. A third complaint against microfinance is that its supply depends entirely on the existence of a solvent demand. Leftist governments disapprove of microfinance's reluctance to lend during economic crisis and its pro-cyclical effect. On a structural level, they also criticize MFIs for focusing on urban service sector activities and small trade, ignoring the primary or secondary sectors that figure so prominently the development plans of socialist movements.

It is useful to analyse the history of power relations that crystallize debt practices in Latin America. Peonaje, i.e., debt bondage, was at the heart of the systems inherited from the colonial era ${ }^{49}$. Indeed, the creation of public institutions, self-governing organizations or commercial endeavours must be understood in terms of the political relations that underpin them. This prism of understanding explains why financial cooperatives, which proliferated in the mid-twentieth century, primarily addressed the least economically subordinated. It also explains why so many Latin American MFIs have ties to religious movements, be they progressive or conservative, Catholic or Protestant ${ }^{50}$. We can also analyse the creation of public banks as way for the state to replace traditional casiquist authorities with new partisan allegiances $^{51}$. According to this perspective, although MFI clients are no longer subject to the obligations of reciprocity that marked colonial history or present-day political clientelism, in return, they must submit to high prices and strict repayment discipline which occasionally translates into a genuine dependence on credit. Conversely, when the government criticizes microfinance and distributes subsidized credit in the name of economic empowerment of the poor-particularly common during election periods - it is striving to create subservience through political means.

Although the left's ideological opposition to microfinance is based on a substantial indictment of the sector, these movements have yet to propose a viable alternative. In all three cases discussed above, high profile public credit programmes have resulted in disappointing results. These failures, like those of comparable programmes in Venezuela ${ }^{52}$ deprive the socialists of the examples they need to confront the orthodoxy they oppose. Still, counter-examples exist 
in Brazil, Chile and Guatemala ${ }^{53}$, where public and private providers are working together to develop truly hybrid methods that ensure financial sustainability. Paradoxically, these examples have not attracted much attention at the regional level and have not yet been replicated in Bolivia, Ecuador or Nicaragua.

\section{Institutional factors affecting microfinance}

Beyond ideologies, local realities are influenced by institutional factors and private interests that affect how conflicts take shape and how they are resolved: through compromise or confrontation. Clear messages paired with coherent measures are essential for building a system that enables collaboration between public and private actors. This has not been the case in Bolivia or Nicaragua, where the governments have taken positions that are not only inconsistent, but even contradictory at times, opposing those of their Ministers and other members of their administrations. Although the phenomenon is familiar to political scientists $^{54}$, it is confusing for microfinance practitioners.

Mediating bodies are crucial under these circumstances, as they can help build frames of reference common to both microfinance institutions and politicians. The technical committees of the Central Bank and ministerial departments played a key role in Bolivia and Ecuador, translating policy intentions into intelligible and enforceable measures. The executive branch's appropriation of these bodies has resulted in a loss of technical capacity, as less experienced staff are more easily influenced by their hierarchical superiors but also by the institutions they are supposed to supervise. It is equally important that microfinance practitioners build consensus around shared positions and rally behind a common spokesperson. In all three countries, microfinance networks ${ }^{55}$ have flourished in a context marked by political tensions, and proved critical to negotiating agreements that improve the sector's visibility in return for greater transparency on microfinance's social utility. They have set up accountability systems that responded to local concerns and publicized microfinance's contribution to the public good in effort to retain their autonomy. Moreover, these networks seek to enhance their legitimacy by forging ties with farmers' organizations, developing rural and agricultural programmes, and promoting alliances with state-owned development banks, such as refinancing agreements with BDP in Bolivia. Some observers argue that these efforts are motivated by MFIs' vested interest in social protection measures, the manna that makes potential borrowers more creditworthy ${ }^{56}$. But this perspective is quite relative; microfinance has developed thus far without this kind of support and increasingly serves the most vulnerable populations. In many cases, microfinance enables governments to overcome the very real challenge of reaching their poorest and most isolated citizens.

Moreover, a more detailed sociological analysis of the elites might be useful to identify opportunities for dialogue and promote goodwill. In many countries, microfinance NGOs are led by left-leaning individuals who entered the sector when their political or civil servant activities were undermined by military repression or structural adjustment. In Ecuador and Bolivia, several MFI managers share close relationships and even personal friendship with policy makers, which has helped create a common ground. In Nicaragua, the tension between microfinance and government owes much to the fact that several MFI managers are former officials of the revolutionary government of the 1980s, now distant from the new government of Daniel Ortega.

\section{Strategic perspectives under constraints}

The increasing tension between microfinance and socialist governments affects MFIs differently, depending on their organizational and operational characteristics. The result is differentiated strategies, which are represented in the following typology: 
SEGMENTATION OF MFIS: SECTOR POLARIZATION AND THE DISAPPEARANCE OF TRANSFORMATIVE MICROFINANCE

\begin{tabular}{|l|l|l|}
\hline $\begin{array}{l}\text { INSTITUTIONAL AND } \\
\text { OPERATIONAL CHARACTERISTICS }\end{array}$ & $\begin{array}{l}\text { PERSPECTIVE OF LEFTIST } \\
\text { GOVERNMENTS }\end{array}$ & SECTOR STRATEGY \\
\hline $\begin{array}{l}\text { Minimalist microfinance: } \\
\text { Commercially aggressive } \\
\text { inproach, private foreign }\end{array}$ & $\begin{array}{l}\text { Segment that is most criticized, but } \\
\text { often not actually threatened by } \\
\text { governments }\end{array}$ & $\begin{array}{l}\text { Consolidate protection through } \\
\text { commercial law. Endorse a } \\
\text { minimum set of social } \\
\text { responsibility principles. }\end{array}$ \\
\hline $\begin{array}{l}\text { Transformative microfinance: } \\
\begin{array}{l}\text { Financially sustainable non-profits, } \\
\text { NGOs and financial cooperatives; } \\
\text { politically independent and } \\
\text { committed to socio-economic } \\
\text { change }\end{array}\end{array}$ & $\begin{array}{l}\text { Segment that is most vulnerable: } \\
\text { existing regulation highly } \\
\text { unfavourable; controversy over ties } \\
\text { to international development aid; } \\
\text { criticized for interest rates; } \\
\text { government negates sub-sector's } \\
\text { autonomy and ability to coordinate } \\
\text { socially oriented or alternative } \\
\text { economic networks }\end{array}$ & $\begin{array}{l}\text { Struggle to be recognised for its } \\
\text { sontribution to development, but; } \\
\text { 'minimalist' or 'solidarity-based' } \\
\text { microfinance. }\end{array}$ \\
\hline $\begin{array}{l}\text { Solidarity-based microfinance: } \\
\text { Subsidized interest rates, directed } \\
\text { credit to specific economic or } \\
\text { social sectors, financial viability } \\
\text { not a priority }\end{array}$ & $\begin{array}{l}\text { Segment supported by socialist } \\
\text { governments, risk of clientelistic } \\
\text { practices, and/or co-optation of } \\
\text { microfinance activities to serve } \\
\text { government's flagship economic } \\
\text { programme. }\end{array}$ & $\begin{array}{l}\text { Transform government's do- } \\
\text { gooder acts into genuine support; } \\
\text { influence government projects. }\end{array}$ \\
\hline
\end{tabular}

For years, the commercial paradigm prioritized competition as a way to improve microfinance market efficiency; today, the excesses of unbridled growth have resulted in debt crises and sometimes abusive practices towards clients. Past efforts to prevent the public actors from regulating social aspects of microfinance or evaluating its contribution to development now appear naïve, and incite scepticism by some governments.

The minimalist vision of microfinance, void of non-financial dimensions such as health, education and local development, was put forth by multilateral institutions as a paragon of good practice. It is now hotly contested. Ironically though, the segment of microfinance that is purely financial and most lucrative is, for the most part, protected from government intervention. It does not depend on the public sector for refinancing and moreover is protected by a solid legal framework that governments are careful not to touch.

Indeed the institutions that risk the most are those that have resisted the commercial paradigm by pursuing professional, sustainable operations while maintaining strong commitment to development goals and social change. These organizations, nearly wiped out by the mainstream regulatory measures of Central Banks that favour private companies and banks, are now trapped in the middle of an increasingly polarized sector dominated by two competing approaches: one driven by commercialization and the other based on public policy. If they fail to demonstrate their relevance, they will have no choice but to retreat to the commercial sphere or submit to the control of public authorities.

\section{Conclusion}

The particularly tense relationship between the government and MFIs in Nicaragua, and the more ambivalent situations in Ecuador and Bolivia, is evidence of the multifaceted, indeed ambiguous, nature of the two sectors. On the one hand, Latin American lefts have the stated objectives to create strong and equitable economic growth; but they are also motivated by the 
desire to broaden and strengthen the clientelistic networks that will allow them to stay in power. On the other hand, microfinance institutions, which emerged in the wake of failed state banks as the only economically viable, development-focused alternative to local financing, have in many cases experienced mission drift, scaling up their operations under an eminently commercial form.

The time has come to revisit both the nature and functioning of financial inclusion mechanisms. Citing the rather bland results of microfinance in terms of economic transformation, socialist-leaning governments are attempting to intervene in the provision of credit services to the poor. But because these programmes are, above all, political tools and lack the human resources to manage them sustainably on a large-scale, they tend to be sporadic and are therefore often complemented with conditional support to existing MFIs. In light of this, it would make sense to negotiate and set up a regulatory framework to prevent abuses, coupled with complementary public policies to improve targeting and impact of microfinance. Instead, political opportunism unfortunately tends to give way to intense but ephemeral competition between existing MFIs and temporary public programmes as well as to piecemeal and often contradictory legal reforms that largely conform with the financial orthodoxy of the previous era.

Paradoxically, this has exacerbated the polarization of the two extremes of the microfinance spectrum in the countries studied. On the one hand, the weakest institutions tend to attract government support, in return for handing over control of operations-even if it means forgoing financial sustainability. On the other, the most commercial institutions protect themselves against the threat of interference by strengthening their ties to the private sector. In short, it would appear that the institutions most directly threatened are those that have achieved viability on their own, using an approach that continues to prioritize local development.

Nevertheless, the debate on how to redefine the roles of the public and private sectors in development finance involves interlocking spheres at local and international levels. It is thus difficult to know how this controversy will evolve. A shift in multilateral support away from commercial microfinance, or the emergence of an alternative approach from a country like Brazil, could still influence national trajectories.

\footnotetext{
${ }^{1}$ This article is based on an original paper translated from French by Mrs. Bonnie Brusky.

${ }^{2}$ R Abramovay, R Magalhães, M Schroeder, 'Social Movements Beyond the Iron Cage: Weak Ties in Territorial Development', World Development, 36(12), 2008, pp. 2906-2920.

${ }^{3}$ P Padilla, 'Las microfinance somos muy politicamente atractivas' Revista Envio, 317, 2008.

${ }^{4} \mathrm{~F}$ Bédécarrats, $\mathrm{R}$ Marconi, 'L'influence de la régulation sur la capacité de la microfinance à contribuer au développement: le cas de la Bolivie', Tiers Monde, 197, 2009, pp. 71-90. Paul Mosley, 'The "Political Poverty Trap": Bolivia 1999-2009', Cuadernos Económicos ICE, 2009, pp. 57-98.

${ }^{5}$ E Rhyne, 'Microfinance Among the Populist' The Huffington Post 11 June 2010.

${ }^{6}$ See, in particular, the international seminar organized by a Latin American network of rural microfinance institutions: Políticas Públicas y Marcos Regulatorios para las Microfinanzas, Seminar FOROLAC-REDCAMIF, Managua, 17 and 18 March 2009.

${ }^{7}$ F Calderon, 'Una inflexión histórica. Situación y cambio político en América Latina socioinstitucional' $C E P A L$ Review, 96, 2008, pp. 121-134.

${ }^{8}$ B Arditi, 'Arguments About the Left Turn in Latin America: A Post-Liberal Politics' Latin American Research Review, 43(3), 2008, pp. 59-81.

9 J G Castañda, 'Latin America’s Left Turn’ Foreign Affairs, 85(3), 2006, pp. 28-43.

${ }^{10}$ M A Cameron, 'Latin America's Left Turn: Beyond Good and Bad' Third World Quarterly, 30(2), 2009, pp. 331-348.

${ }^{11}$ P Hall, RTaylor, 'Political Science and the Three New Institutionalisms' Political Studies, 44(5), 1996936 957. B Palier, Y Surel, 'Les “trois I” et l'analyse de l'État en action', French Review of Political Science, 55, 2005, pp. 7-32.
} 
${ }^{12} \mathrm{~J}$ C Moreno-Brid, I Paunovic, 'What is New and What Is Left of the Economic Policies of the New Left Governments in Latin America' International Journal of Political Economy, 37(3), 2008, pp. 82-108.

${ }^{13}$ J Beasley-Murray, M A Cameron, E Hersheberg, 'Latin America's Left Turn: an introduction', Third World Quarterly, 30(2), 2009, pp. 319-330.

${ }_{14}$ Ibid., pp. 328.

${ }^{15}$ C Trivelli, H Venero, 'Banca de desarrollo para el agro: experiencias en curso en América Latina' Lima, Instituto de Estudios Peruanos, 2007.

${ }^{16}$ M F. Long (Ed.), World Development Report, New York, World Bank-Oxford University Press, 1989.

${ }^{17}$ D W Adams, D H Graham, J D Von Pischke, Undermining Rural Development with Cheap Credit, Boulder, Westview Press, 1984.

${ }^{18}$ J Bastiaensen, 'Non-Conventional and Rural Finance and the Crisis of Economic Institutions in Nicaragua', in: J P de Groot (Ed.), Sustainable Agriculture in Central America London, Macmillan Press, 1997, pp.191-209. F Doligez, Innovations financières, financement du développement et dynamiques rurales. Comparative studies in Benin, Guinea and Nicaragua, Nanterre, Université de Paris X, doctoral thesis in Economics, 2002.

${ }^{19} \mathrm{H}$ Weber, 'The Imposition of a Global Development Architecture: The Example of Microcredit' Review of International Studies, 28, 2002, pp. 537-555.

${ }^{20}$ J Morduch, 'The Microfinance Promise', Journal of Economic Literature, 37(4), 1999 1569-1614.

${ }^{21}$ B Helms, Access for All - Building Inclusive Financial Systems, Washington DC, CGAP, 2006.

${ }^{22}$ R Martinez Ramirez 2009 Latin America and Caribbean Microfinance Analysis and Benchmarking Report, Washington DC, The MIX, 2010.

${ }^{23}$ R Rosenberg, A Gonzalez, S Narain The New Moneylenders: Are the Poor Being Exploited by High Microcredit Interest Rates? Washington DC, CGAP Occasional Paper, 2009.

${ }^{24}$ Yield average $33.8 \%$ for the entire continent. R. Martinez Ramirez 2009 Latin America and Caribbean Microfinance Analysis and Benchmarking Report, op. cit. pp. 18.

${ }^{25}$ I Guérin, C Lapenu, F Doligez, 'La microfinance est-elle socialement responsable? Introduction', Revue Tiers Monde, 197, 2009, pp. 5-16.

${ }^{26}$ R Marconi, P Mosley, 'Bolivia During the Global Crisis 1998-2004: Towards a Macroeconomics of Microfinance', Journal of International Development, 18(2), 2006, pp. 237-261.

${ }^{27} \mathrm{~S}$ Morvant-Roux, 'Accès au microcrédit et continuité des dynamiques d'endettement au Mexique: Combiner anthropologie et économétrie', Revue Tiers Monde, 197, 2009, pp. 109-130.

F Bédécarrats, R Marconi, 'L'influence de la régulation sur la capacité de la microfinance à contribuer au développement: le cas de la Bolivie', op. cit 76.

${ }^{29}$ R Marconi, P Mosley, 'Bolivia During the Global Crisis 1998-2004: Towards a Macroeconomics of Microfinance' op. cit.

${ }^{30}$ H Do Alto, P Stefanoni, Nous serons des millions: Evo Morales et la gauche au pouvoir en Bolivie, Paris, Raisons d'Agir, 2008.

${ }^{31}$ R Vogel, A Gomez, G Tabares, 'Regulation and Supervision of Microfinance Activities: The Bolivian Case Study', Washington DC, USAID / MBP, 2000.

${ }^{32}$ F Bédécarrats, $\mathrm{R}$ Marconi, 'L'influence de la régulation sur la capacité de la microfinance à contribuer au développement: le cas de la Bolivie', op. cit.

${ }^{33}$ Source: Compiled from data from the Superintendencia de Bancos (www.superintendencia. Gob.ni / index.php? Temp cont $=\&$ id $=10 \&$ Seccion $=1$, accessed 12/05/2010), and those of Asomif, www.asomif.org/index.php?option=com content\&view=article\&id=28\&Itemid=5 , Accessed 12/05/2010). ${ }^{34} \mathrm{~J}$ Bastiaensen, P Marchetti, 'A critical review of CGAP-IADB Policies Inspired by the Fondo de Desarrollo Local, Nicaragua', Enterprise Development and Microfinance, 18(2-3), 2007, pp. 143-157.

${ }^{35}$ Thus, multilateral and bilateral agencies in 2008 accounted for $60 \%$ and $30 \%$ of funding sources for Procredit, the largest microfinance bank of the country, operating mainly in urban areas, compared to $13 \%$ and $14 \%$ for FDL, the largest, unregulated and mainly rural microfinance NGO in the country. Conversely, social and commercial investment funds accounted for $11 \%$ of Procredit's funding, but 50\% of FDL's. Source: statistics compiled by P Acabar, cited in D Roodman's Microfinance Blog (2010) http://blogs.cgdev.org/open_book/2010/03/who-inflated-the-bubbles.php \# comment-4365 (Accessed 25 April 2010)

${ }^{36}$ M Flaming, E Duflos, B Helms, H Siedek, R Summerlin, S Duarte Country-Level Effectiveness and Accountability Review, Washington DC, CGAP Aid Effectiveness Initiative, 2005.

${ }^{37}$ J L Rocha Gómez, 'Crisis institucional en Nicaragua: entre un Estado privatizado y un Estado monarquizado', Nueva Sociedad, 228, July-August 2010, pp. 4-13, http://www.nuso.org/ upload/articulos/3702_1.pdf . .

${ }^{38}$ Translation of Daniel Ortega's speech transcribed in El Nuevo Diario, 14 July 2008. 
39 In the field, many debtors and MFIs now tend to negotiate bilaterally and very pragmatically the restructuration of debt in exchange of the (legally, but not really) confiscated properties, thereby turning this page as soon as possible.

${ }^{40} \mathrm{C}$ Trivelli, H Venero, 'Banca de desarrollo para el agro: experiencias en America Latina in curso', op. cit. pp. 88-102.

${ }^{41}$ S Basabe-Serano, 'Ecuador: reforma constitucional, nuevos actores políticos y viejas prácticas partidistas' Revista de ciencia política, 29(2), 2009, p. 381-406.

${ }^{42}$ The concept of social economy refers here to organizations engaged in economic activities defined by the status of collective ownership, such as cooperatives, mutualities, associations or unions. See J-L Laville (Ed.), L'économie solidaire. Une perspective internationale, New and updated edition, Paris, Hachette, Pluriel, 2007, pp. 31-38.

M Zeller, C Lapenu, M Greeley, Measuring social performance of micro-finance institutions: A proposal. Washington (DC): Argidius Foundation-CGAP, 2003.

${ }^{44}$ E Rhyne, 'Microfinance among the populists' op. cit.

${ }^{45}$ S Strange, The Retreat of the State, Cambridge, Cambridge University Press, 1996.

${ }^{46}$ A Rodriguez Carmona, El Proyectorado: Bolivia tras 20 años de ayuda externa, La Paz, Intermón Oxfam, 2008.

${ }^{47}$ See G Toro, La pobreza: a gran negocio-análisis crítico sobre Oeneges, Microfinancieras y Banca La Paz, Oficina contra la usura Bancaria-Mujeres creando, 2009.

${ }^{48}$ N Bobbio, Derecha e izquierda: razones y significados de una distinción política, Madrid, Taurus, 1995.

${ }^{49}$ M-N Chamoux, D Dehouve, C Gouy-Gilbert, M Pépin-Lehalleur, Prêter et emprunter. Pratiques de crédit au Mexique, Paris, Éditions de la Maison des sciences de l'homme.

${ }^{50}$ In Nicaragua, for example, FDL was established by Jesuits and Prestanic by the Council of Protestant Churches. Compartamos, the largest Mexican MFI, was founded and is still largely controlled by the traditionalist Legionaries of Christ. (In Bolivia and Ecuador faith-based MFIs are less important.) Microfinance has even been mentioned, albeit in very vague terms, in a Papal Encyclical, Benedict XVI Encyclical Letter Caritas in Veritae of the Supreme Pontiff on integral human development in charity and truth, Rome, Vatican, 29 June 2009, http://www.vatican.va/holy_father/benedict_xvi/encyclicals/documents/hf_benxvi_enc_20090629_caritas-in-veritate_en.html It should be noted, however, that in line with their ideological and programmatic differences these faith-based organizations do not necessarily share similar political positions with respect to the role of microfinance.

${ }^{51}$ D Lehmann, Democracy and Development in Latin America: Economics, Politics and Religion in the Postwar Period, Philadelphia, Temple University Press, 1990.

${ }^{52}$ M González de Kauffman, 'El pago de servicios públicos: garantía para la devolución de microcréditos del programa "Ciudadanía Plena” en Maracaibo, Venezuela', Revista de Ciencias Sociales, 15(4), December 2009, p. 363-707. M Penfold-Becerra, 'Clientelism and Social Funds: Evidence from Chávez's Misiones', Latin American Politics and Society, 49, 2007, p. 63-84.

${ }^{53}$ Banco do Nordeste in Brazil, INDAP in Chile and BANRURAL in Guatemala. For Brazil, see R Abramovay, R Magalhães, M Schroeder, 'Social Movements Beyond the Iron Cage: Weak Ties in Territorial Development', op. cit. and C Trivelli, H Venero, 'Banca de desarrollo para el agro: experiencias en America Latina in curso', op. cit. for the two others.

${ }^{54}$ R Dahl, Polyarchy: Participation and Opposition, New Haven, Yale University Press, 1975.

${ }^{55}$ ASOMIF (www.asomif.org), founded in 1992 in Nicaragua, Red Financiera Rural (www.rfr.org.ec), founded in 2000 in Ecuador, FINRURAL (www.finrural-bo.org) and ASOFIN (www.asofinbolivia.com) created in 1993 and 1999, respectively, in Bolivia.

${ }^{56}$ F Ramírez Gallegos, Analía Minteguiaga, 'El nuevo tiempo del Estado. La política posneoliberal del correísmo', OSAL, 22, September 2008, pp. 87-103,

http://bibliotecavirtual.clacso.org.ar/ar/libros/osal/osal22/D22RamirezGMinteguiaga.pdf .. 